\title{
Inside the Polish media firms: Accountability and transparency in the newsrooms ${ }^{1}$
}

\begin{abstract}
Although the majority of mechanisms and instruments which aim to support media ethics and journalistic professionalization in Poland were introduced at an early stage of political and social transformation in the 1990s, media accountability is still in the making. The moderate level of journalistic professionalization might be explained by the weakness of existing self-regulatory mechanisms (codes of journalistic conduct, The Council of Media Ethics), divisions within journalistic communities (left wing-oriented vs. right-wing politically oriented) and the growing economic pressure. Bearing in mind that decision-making processes, supportive management as well as organizational structures and cultures might have an impact on journalistic behaviour and the understanding of roles and journalistic quality, this paper will go a long way in explaining the state of media accountability and transparency from the perspective of newsrooms. Referencing to the outcomes of empirical international research project "Media Accountability and Transparency in Europe (MediaAcT)" (2010-2013) the study will provide evidence similarities and differences in the perception of tools and existing practices by journalists from different types of media and job positions.
\end{abstract}

Key words: media accountability, transparency, media management, Poland

\section{Introduction}

$\mathbf{T}$ The rapid development of new media and technologies, together with changes in the business models of media (open innovation, crowdsourcing) and more active users' behaviour (citizen journalism, media activism) generated new approaches to the role of journalism in contemporary societies and models of journalism. The examination of professional roles in the era of spreadable media (Jenkins et al., 2013), creative publics

1 The information in this document is the outcome of the EU project "Media Accountability and Transparency (MediaAcT)". The research leading to these results has received funding from the European Union Seventh Framework Programme (FP7/2007-2013) under grant agreement no. 244147. 
(Shirky, 2008), and the culture of connectivity (Van Dijck, 2013), often include discussions on journalism culture, norms, values and behaviours. Fengler (2012), Heikkilä et al. (2012) and von Krogh (2012) have emphasized the need to rethink and redefine the ways in which contemporary media enterprises respond to the public for the quality and consequences of publication. The role that accountability and transparency play in the everyday running of a media outlet is becoming crucial as the processes of production and consumption blend.

Several policy-making initiatives and studies conducted in Poland have already identified a need for a large-scale evaluation of journalism culture. However, with the exception of studies conducted by Stępińska and Ossowski (2011), Szot (2013), Stępińska and Głowacki (2014), Nygren and Dobek-Ostrowska (2015), the internal organizational perspective has not become subject of systematic investigation to date. The data gathered in the "Media Accountability and Transparency (MediaAcT)" (2010-2013) project - an international study on emerging media accountability practices in selected European countries and beyond - has identified several characteristics of Polish journalism culture, which included the growing commercialization and moderate level of journalistic professionalization, typified by the weakness of existing self-regulatory mechanisms (codes of journalistic conduct, The Council of Media Ethics), political divisions within journalistic communities as well as differences in the assessment of media accountability tools and practices from the perspective of newsrooms. Bearing in mind that organizational working conditions and internal processes have an impact on the perception and understanding of values and norms, a look inside the media firms becomes critical to fully understand the nature of Polish journalism.

This paper takes an internal view on news outlets in order to shed lights on media accountability and transparency. The goal is to examine the available tools and to compare journalistic perceptions with practices connected with internal criticism, commitment to professional standards, transparency of news development as well as the way in which media enterprise respond to external criticism (dialogue transparency). The results of empirical study are likely to indicate the extend to which media types and job positions evidence similarities and differences in assessing the importance of selected tools and the ways in which they work in practice. This paper aims to open-up the discussions on the importance of internal processes, the role of supportive management, dynamics of changing media environment as well as a need for developing an effec- 
tive methodological framework for future studies on journalism and its professionalization.

The questions addressed here are the following: How do Polish media professionals evaluate the importance of tools supporting media accountability and transparency in the newsrooms? How do they perceive daily practices related to internal and external criticism, commitment to professional standards and interaction with the publics? What are the similarities and differences in the perception of available tools and actual practices across different media types and positions in the newsrooms?

\section{Media accountability and transparency}

While there is much that could be written about accountability systems, mechanisms, tools and practices, it might be difficult to identify one universal approach to accountability in the media (Bertrand, 2000; von Krogh, 2012). Media accountability might be understood as "any informal institution [...] performed by both media professionals and media users, which intends to monitor, comment on and criticize journalism and seeks to expose and debate problems of journalism" (Fengler et al., 2011, p. 20), "the value and essential tenet of media governance" (EBU, 2015), or "dynamic interaction between the parties involved" (de Haan, 2012, p. 62). Evers and Groenhart (2010) argue that media accountability requires sufficient level of transparency at different levels of news production. It includes actor transparency (before publication), production transparency (during the process of publication) and dialogue transparency (after publication). In addition to this, Wyss and Keel (2009, p. 116) highlight the role of professional standards and the system of management "that systematically treats the interests of the stakeholders and functions as an instrument to establish a culture of responsibility, or media accountability".

A media enterprise can facilitate accountability through in-house criticism, internal communication as well as management which encourages debates on quality issues. All of this is further supported by publishing of editorial guidelines, ethical codes and mission statements as well as information about editorial decisions and links to original sources and documents. Finally, critical audience interaction is observed when a given media enterprise creates tools for participation, engagement and for providing response to external criticism (correction boxes, letters to the 
editor, complaint policies and user comments online) (Evers, Groenhart, 2010; Heikkilä et al., 2012, 2014).

The adoption of each practice can be analyzed when taking into account micro-level perspective, highlighting - above all - the age and size of a media company, type of media, organizational chart, funding systems, ownership (public service vs. private), strategy and vision, motivation strategies and HR policies, salary and employment conditions, professional autonomy, as well as adaptation of new technologies and supportive organizational culture. Groenhart and Evers (2014) have recently looked at the extent to which media segments, job positions and the age of media professionals, contribute to the understanding of norms and evaluation of the existing instruments of media accountability. The authors have demonstrated that European journalists attach a great value to aspects of organizational transparency and concluded that "historical and political context of individual countries clearly causes divergence in journalists' faith in various media accountability instruments" (Groenhart, Evers, 2014, p. 143).

\section{Methodology}

The arguments of the article are based on the findings from empirical part of the study entitled "Media Accountability and Transparency (MediaAcT)" (2010-2013)2. Due to the lack of official data on the number of journalists working in the Polish news media, the number of active journalists was estimated at the level of 11,989 people on the basis of information gathered from existing media organizations. Potential respondents were divided into specific sectors, including daily newspapers, magazines, radio, TV, press agency and the news online media outlets. Estimations made at the first stage were further verified in accordance to different job positions. Following the solutions from other countries involved, the distinction between operational (media reporters) and managerial (chief editors, leading editors) positions was estimated at the approx. 70 percent vs. 30 percent. The final sample with additional freelance representatives

2 "Media Accountability and Transparency (MediaAcT)" study was conducted in Austria, Estonia, Finland, France, Germany, Italy, Jordan, The Netherlands, Poland, Romania, Spain, Switzerland, Tunisia and United Kingdom. For aims and objectives of MediaAcT see www.mediaact.eu. For complete description of project methodology see Eberwein et al. (2014). 
in press and online news media was established (Table 1). The data in Poland was gathered through the online questionnaire in the period of May-June 2011.

Table 1

Sample of Polish journalists surveyed

\begin{tabular}{||l|c|c|c|c|c||}
\hline \multicolumn{1}{|c|}{ Types of media } & Freelancers & Owners & $\begin{array}{c}\text { Managers } \\
\text { (Leading and } \\
\text { chief editors) }\end{array}$ & $\begin{array}{c}\text { Reporters } \\
\text { (Journalists) }\end{array}$ & Total \\
\hline Daily newspapers & 1 & 2 & 10 & 24 & 37 \\
\hline Magazines & 2 & 1 & 3 & 13 & 19 \\
\hline Public radio & 0 & 0 & 4 & 8 & 12 \\
\hline Private radio & 0 & 0 & 3 & 5 & 8 \\
\hline Public TV & 0 & 0 & 2 & 6 & 8 \\
\hline Private TV & 0 & 0 & 2 & 8 & 10 \\
\hline Online news media & 1 & 1 & 1 & 1 & 4 \\
\hline Press agency & 0 & 0 & 1 & 1 & 2 \\
\hline Total & $\mathbf{4}$ & $\mathbf{4}$ & $\mathbf{2 5}$ & $\mathbf{6 6}$ & $\mathbf{1 0 0}$ \\
\hline
\end{tabular}

Source: MediaAcT data.

In order to meet the paper's objectives we draw here on selected findings out of 18 questions in the survey, which were grouped in accordance to perception of norms of media accountability and evaluation of actual practices in the newsrooms. All the data the percentage of respondents who supported the statements (agreed and fully agreed) which were evaluated by journalists on the scale ( 1 - I totally disagree, 5 - I fully agree). The analysis was conducted following the general tendencies observed for the whole sample of Polish journalists as well as potential similarities and differences between journalists from diverse types of media and job positions. However, due to the small sample of journalists representing online media firms (4 media professionals surveyed) and the Polish press agency ( 2 media professionals surveyed), responses from these sectors were excluded when comparing different segments of media. Similarly to this, the analysis of different job positions does not include responses from four freelancers and four participants regarded as the owners of the media.

\section{Perception of available tools}

Overall, the potential of tools supporting media accountability in the newsrooms were positively evaluated by majority of the Polish respond- 
ents. A large number of them agreed that publishing information about media ownership (73 percent of respondents) and links to original sources of information (62 percent of respondents) are among critical obligations of the media. Interestingly, 48 percent of media professionals surveyed supported the idea of employing readers' editor/media ombudsman, although this type of institution has not yet been created in any Polish enterprise. On the other hand, 23 percent of journalists surveyed underlined the need for explanation of newsroom decisions on the selection of news and story development (Figure 1).

\section{Figure 1. Perception of available tools by Polish journalists surveyed. "Media organization should..." (per cent of respondents who agreed and fully agreed)}

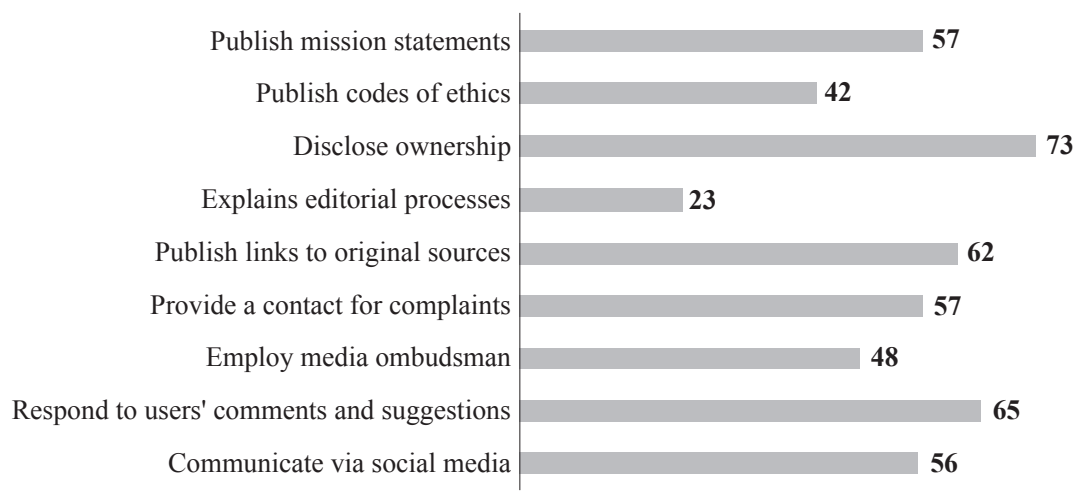

Source: MediaAcT data.

In-depth analysis across different media segments (Table 2) further evidenced that journalists from public service television provided the biggest support for publishing mission statement and codes of ethics online. This might be due to the fact that the public service media remit with obligations and values are defined both in the media law and editorial guide$\operatorname{line}^{3}$. Although there was a general agreement that media organization should reveal information about its ownership, the support was the lowest

3 See for instance article 21 of Broadcasting Act of Poland (1992) and Zasady etyki dziennikarskiej w Telewizji Polskiej SA [Ethical standards of journalists from Polish Television] http://centruminformacji.tvp.pl/22263456/zasady-etyki-dziennikarskiej-w-telewizji-polskiej-sa-informacja-publicystyka-reportaz-dokument-edukacja, 15.01.2016. 
in printed press enterprises (newspapers and magazines) and private radio which mostly belong to international media groups.

At the same time, 16 percent of respondents from magazines declared there is a need to explain editorial processes and 53 percent of them emphasized the need for publishing links to original sources. In both cases the level of support was the lowest across different types of media under the study. Interestingly, no significant differences between public service and private radio firms was observed when evaluating the need for transparency in news production.

When looking at practices supporting dialogue transparency 36 percent of journalists and managers from public service radio emphasized a need for providing channels for complaints. In addition to this, 45 percent of them supported the idea of responding to users' comments and suggestions. Communication with the public via social media was most important for professionals in private radio and newspapers. The lowest support in this regard was indicated by respondents from television channels (both public service and private) and magazines. The data are interesting due to the fact that majority of news items in these two segments have done well when developing their Facebook and Twitter accounts.

Table 2

Perception of available tools across different types of media (per cent and number of respondents who agreed and fully agreed)

\begin{tabular}{|c|c|c|c|c|c|c|c|c|c|c|c|c|}
\hline \multirow[t]{2}{*}{ 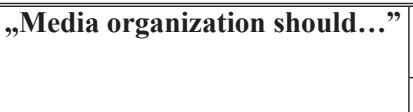 } & \multicolumn{2}{|c|}{$\begin{array}{l}\text { News- } \\
\text { papers }\end{array}$} & \multicolumn{2}{|c|}{$\begin{array}{c}\text { Maga- } \\
\text { zines }\end{array}$} & \multicolumn{2}{|c|}{$\begin{array}{c}\text { Public } \\
\text { radio }\end{array}$} & \multicolumn{2}{|c|}{$\begin{array}{c}\text { Private } \\
\text { radio }\end{array}$} & \multicolumn{2}{|c|}{$\begin{array}{c}\text { Public } \\
\text { TV }\end{array}$} & \multicolumn{2}{|c|}{$\begin{array}{c}\text { Private } \\
\text { TV }\end{array}$} \\
\hline & $\mathbf{N}$ & $\%$ & $\mathbf{N}$ & $\%$ & $\mathbf{N}$ & $\%$ & $\mathbf{N}$ & $\%$ & $\mathbf{N}$ & $\%$ & $\mathbf{N}$ & $\%$ \\
\hline $\mid \mathbf{F}$ & 36 & 63 & 19 & 58 & 11 & 45 & 8 & 37 & 8 & 87 & 10 & 50 \\
\hline Publ & 37 & 38 & 19 & 37 & 11 & 62 & 8 & 63 & 8 & 75 & 10 & 40 \\
\hline Discl & 37 & 70 & 19 & 73 & 11 & 82 & 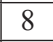 & 75 & 8 & 99 & 9 & 99 \\
\hline Expla & 37 & 28 & 19 & 16 & 11 & 27 & 8 & 26 & 8 & 38 & 10 & 10 \\
\hline Publ & 36 & 64 & 19 & 53 & 11 & 63 & 8 & 63 & 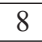 & 88 & 10 & 80 \\
\hline Prov & 37 & 81 & 19 & 58 & 11 & 36 & 8 & 75 & 8 & 75 & 10 & 80 \\
\hline Emp & 37 & 49 & 19 & 37 & 11 & 64 & 8 & 38 & 8 & 51 & 10 & 80 \\
\hline Respond to & 37 & 73 & 19 & 53 & 11 & 45 & 0 & 63 & 8 & 75 & 10 & 70 \\
\hline Communicate via social media & 37 & 65 & 19 & 42 & 11 & 45 & 8 & 75 & 8 & 50 & 10 & 40 \\
\hline
\end{tabular}

Source: MediaAcT data.

The data also showed that reporters who were responsible for gathering and publishing news stories were more likely to positively assess the majority of tools supporting accountability and transparency. Support for 
publishing mission statements and responding to users' comments and suggestions was bigger when looking at the responses by chief and leading editors (Table 3).

Table 3

Perception of available tools across different job positions (per cent of respondents who agreed and fully agreed)

\begin{tabular}{||l|c|c|c|c||}
\hline \multirow{2}{*}{ „Media organization should...” } & \multicolumn{2}{|c|}{ Managers } & \multicolumn{2}{c|}{ Reporters } \\
\cline { 2 - 5 } & $\mathbf{N}$ & $\mathbf{\%}$ & $\mathbf{N}$ & \% \\
\hline Publish its mission statement & 25 & 64 & 66 & 57 \\
\hline Publish its codes of ethics & 25 & 40 & 66 & 45 \\
\hline Disclose ownership & 25 & 72 & 65 & 77 \\
\hline Explain editorial processes & 25 & 12 & 66 & 27 \\
\hline Publish links to original sources & 25 & 60 & 65 & 68 \\
\hline Provide a contact for complaints & 25 & 64 & 66 & 70 \\
\hline Employ media ombudsman & 25 & 48 & 66 & 48 \\
\hline Respond to users' comments & 25 & 68 & 66 & 66 \\
\hline Communicate via social media & 25 & 56 & 66 & 58 \\
\hline \hline
\end{tabular}

Source: MediaAcT data.

\section{Evaluation of actual practices}

Concerning the evaluation of actual practices (Figure 2) 33 percent of respondents declared that their media outlets publish mission statements and/or codes of ethics online. More than 60 percent declared that media managers played a role when maintaining high standards of journalism both under difficult circumstances and in situations in which journalistic work was challenged by members of the public. Additionally, 57 percent of reporters and managers noted that the management reacted and/or encouraged others to react for users' complaints. A positive assessment of the role of managers in internal criticism and debates on quality issues was indicated by 35 percent of all media professionals.

In-depth studies of different media types revealed that the practice of publishing high standards online was the most often observed in daily newspapers and on public service radio (43 percent and 36 percent accordingly). Contrary to this, 13 percent of respondents from private radio and 21 percent from magazines indicated their organizations used the practice on the regular basis. As noted by Kuś (2011) and Heikkilä et 
Figure 2. Evaluation of newsroom practices by Polish journalists surveyed (per cent of respondents who agreed and fully agreed)

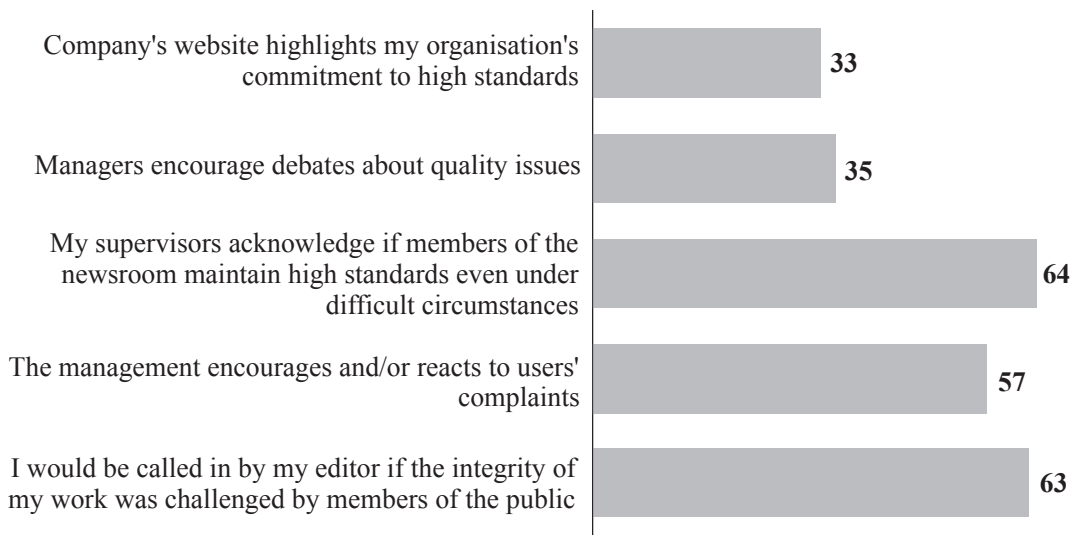

Source: MediaAcT data.

al. (2012), other tools such as platforms explaining editorial processes and publishing links to original sources of information, have not yet been widely adopted by the Polish media firms. The authors noted that among the most advanced mechanisms were those supporting dialogue transparency, such as online comments in news (Kuś, 2011; Heikkilä et al., 2012). In public media enterprises the opportunity to issue a complaint was made widely available through the special form published on the website of a given media enterprise and the National Broadcasting Council (Głowacki, 2015).

The role of management in fostering both internal and external criticism was the lowest in public service TV. For instance 13 percent of public media professionals noted that managers supported debates about quality issues and 38 percent indicated their positive role in encouraging to react to complaints from users. The most positive assessment of management role in newsroom debates (43 percent) and involvement in promotion of high standards ( 73 percent) was evidenced by respondents from daily newspapers. High agreement for managerial role in fostering dialogue transparency across different types of media has proven that the managerial attitude have been seen as reactive rather than proactive. Journalists from daily newspapers and magazines were more likely to be called in by their leading and chief editors if journalistic work was challenged by the publics (Table 4). 
Table 4

Evaluation of newsroom practices across different types of media (per cent and number of respondents who agreed and fully agreed)

\begin{tabular}{|l|c|c|c|c|c|c|c|c|c|c|c|c||}
\hline & $\begin{array}{c}\text { News- } \\
\text { papers }\end{array}$ & \multicolumn{2}{|c|}{$\begin{array}{c}\text { Maga- } \\
\text { zines }\end{array}$} & \multicolumn{2}{c|}{$\begin{array}{c}\text { Public } \\
\text { radio }\end{array}$} & \multicolumn{2}{c|}{$\begin{array}{c}\text { Private } \\
\text { radio }\end{array}$} & \multicolumn{2}{c|}{$\begin{array}{c}\text { Public } \\
\text { TV }\end{array}$} & \multicolumn{2}{|c|}{$\begin{array}{c}\text { Private } \\
\text { TV }\end{array}$} \\
\cline { 2 - 12 } & $\mathbf{N}$ & $\mathbf{\%}$ & $\mathbf{N}$ & $\mathbf{\%}$ & $\mathbf{N}$ & $\mathbf{\%}$ & $\mathbf{N}$ & $\mathbf{\%}$ & $\mathbf{N}$ & $\mathbf{\%}$ & $\mathbf{N}$ & $\%$ \\
\hline $\begin{array}{l}\text { Company's website highlights } \\
\text { my organization's commitment } \\
\text { to high standards }\end{array}$ & 37 & 43 & 19 & 21 & 11 & 36 & 8 & 13 & 8 & 25 & 10 & 30 \\
\hline $\begin{array}{l}\text { Managers encourage debates } \\
\text { about quality issues }\end{array}$ & 37 & 43 & 19 & 42 & 11 & 36 & 8 & 26 & 8 & 13 & 10 & 30 \\
\hline $\begin{array}{l}\text { My supervisors acknowledge } \\
\text { if members of the newsroom } \\
\text { maintain high standards even } \\
\text { under difficult circumstances }\end{array}$ & 37 & 73 & 19 & 69 & 11 & 63 & 8 & 63 & 8 & 51 & 10 & 60 \\
\hline $\begin{array}{l}\text { The management encourages } \\
\text { and/or reacts to audience com- } \\
\text { plaints }\end{array}$ & 37 & 68 & 19 & 42 & 11 & 55 & 7 & 50 & 8 & 38 & 10 & 70 \\
\hline $\begin{array}{l}\text { I would be called in by my edi- } \\
\text { tor if the integrity of my work } \\
\text { was challenged by members of } \\
\text { the public }\end{array}$ & 37 & 68 & 19 & 69 & 11 & 63 & 7 & 57 & 8 & 51 & 10 & 60 \\
\hline
\end{tabular}

Source: MediaAcT data.

In every case actual practices were more often positively evaluated by media managers than reporters (Table 5). For instance, 48 percent of chief and leading editors acknowledged that media organization published ethical codes and mission statements. The biggest differences between managerial and operational level were observed when evaluating whether managers acknowledged high standards of journalism and encouraged debates about quality-related issues. More than 60 percent of reporters agreed they would be called by their superiors in case their work was criticised by the public.

Table 5

\section{Evaluation of newsroom practices across different job positions (per cent of respondents who agreed and fully agreed)}

\begin{tabular}{||c|c|c|c|c||}
\hline \hline & \multicolumn{2}{|c|}{ Managers } & \multicolumn{2}{c|}{ Reporters } \\
\cline { 2 - 5 } & $\mathbf{N}$ & $\mathbf{\%}$ & $\mathbf{N}$ & $\mathbf{\%}$ \\
\hline 1 & 2 & 3 & 4 & 5 \\
\hline $\begin{array}{l}\text { Company's website highlights my organization's } \\
\text { commitment to high standards }\end{array}$ & 25 & 48 & 66 & 30 \\
\hline
\end{tabular}




\begin{tabular}{||l|c|c|c|c||}
\hline \multicolumn{1}{|c|}{1} & 2 & 3 & 4 & 5 \\
\hline Managers encourage debates about quality issues & 25 & 56 & 66 & 27 \\
\hline $\begin{array}{l}\text { My supervisors acknowledge if members of the } \\
\text { newsroom maintain high standards even under dif- } \\
\text { ficult circumstances }\end{array}$ & 25 & 88 & 66 & 57 \\
$\begin{array}{l}\text { The management encourages and/or reacts to audi- } \\
\text { ence complaints }\end{array}$ & 25 & 72 & 65 & 54 \\
\hline $\begin{array}{l}\text { I would be called in by my editor if the integrity of } \\
\text { my work was challenged by members of the public }\end{array}$ & 25 & 76 & 65 & 64 \\
\hline
\end{tabular}

Source: MediaAcT data.

\section{Conclusions}

The development of new platforms and services in the network era offer new ways through which media organizations might be held into account for the quality and consequences of publication. The new advanced, participatory and web-based models of media accountability require sufficient level of transparency and adaptation of tools and practices fostering commitment to professional standards, media criticism as well as production and dialogue transparency. Media organizations, together with their management structures, cultures and processes play significant role in the discussions on problems of journalism as well as opening-up media firms for internal and external engagement.

The Polish journalists surveyed in the MediaAcT study declared high level of support when being asked about norms of media accountability and what the newsrooms should do. With the exception of tools supporting production transparency and explaining editorial choices related to news, they declared relatively high level of agreement toward different obligations of media. At the same time, a discrepancy between the norms of accountability and assessments of the actual practices in their news organizations was observed. This tendency was similar to the data collected in other countries from the MediaAcT consortium (Groenhart and Evers, 2014). This is due to the fact that some practices might be difficult to achieve on a regular basis and that they depend on media organization's willingness for being change-ready to evolve and/or adapt. The relatively low assessment of both available tools and adopted practices supporting production transparency showed that Polish journalists might have not necessarily wanted to share all the information about news development with the public. More in-depth questions in the survey could 
further evidence whether their attitude resulted from the feeling that sharing too much information might challenge their journalistic authority and autonomy.

Some tendencies related to potential similarities and differences across the segments of media have been observed. One of the most visible findings here was related to high level of support for dialogue transparency - both at the level of norms and practices - in daily newspapers. Journalists from this segment positively evaluated the role of media managers when maintaining high professional standards and reacting to users' complaints. High scores in this regard might be explained by tradition and history of newspapers as well as mission statements, that were also highly evaluated in the group of media obligations. The remaining question here is to what extend distinctions between high quality and tabloid newspapers influence newsroom practices and the assessments of external criticism. Since the most popular newspaper in Poland is a tabloid Fakt, additional research could demonstrate potential differences in the understanding and impact of mission statements and professional codes of ethics. Interesting findings from the comparative study across media types also related to the distinction between public service and private media firms. The initial assessment connected with public media obligations toward society and democracy defined in media law, codes of ethics and mission statements was proved when looking at relatively high agreements for tools supporting actor transparency. Similarly to their colleagues from private media, respondents from public service radio and public service TV expressed dichotomy between norms and the actual practices; 25 percent professionals from public service television declared that this organization highlighted commitment to professional standards of journalism online.

Moreover, 36 percent of respondents from public service radio indicated a need for providing contact for complaints. These examples suggest that the idea of responsive, advanced and open public media enterprise might have not yet been fully recognized. In addition to this, media professionals surveyed indicated the rather passive role of public media managers; commitment towards internal and external criticism was the lowest across different media segments under the study. All of this could be further explained when taking into account organizational structures, hierarchy and internal communications between professional and management levels. In most of the cases analysed the role of managers was seen as reactive rather than proactive. The most proactive managerial attitudes were observed by media professionals from the daily newspapers. 
Finally, the data gathered evidenced differences between the assessment of tools and actual practices between job positions. While reporters were generally more positive towards norms of accountability, leading and chief editors were among those who more often observed a given practice in the daily work in the newsrooms. Overall, leading and chief editors across different types of media were the most positive in comparison to other media professionals when evaluating their own roles in maintaining high professional standards under difficult circumstances and also in the case when journalistic work was challenged by the public. Contrary to this, reporters were not that often supportive when assessing the level of quality management, which proved that their perception of news practices might have been slightly different. The way how managers were evaluated by journalists in Poland did not fully support general findings in countries where MediaAcT survey was conducted. Following the conclusions by Groenhart and Evers (2014) the low perception of quality management in the Polish firms might have resulted from rather critical evaluation of internal criticism. As the previous data confirmed, the majority of journalists surveyed indicated rather reactive role of leaders and chief editors. At the same time, respondents from this category supported the majority of accountability norms (production transparency excluded). In line with this, one of the conclusions could be that reporters across different media segments in Poland were open for external criticism and professional development.

All the data presented and explained above shall be read carefully. Firstly then, the goal of this research was to show the general tendencies and was based on data gathered from different groups (media segments and job positions) which sometimes were significantly different in terms of representative number in each category. Other weaknesses were related to the fact that online MediaAcT questionnaire created only limited opportunities to measure the role of organizational conditions when holding media enterprise into account. Although references to job positions and media segments revealed some regularities, they shall only be treated as starting points for future research and discussion. Thus, the contributions of the newsrooms could be further complemented by inclusion of additional variables, such as internal communication processes, working and employment conditions, professional autonomy, and so on. The presented approach might have failed to address changes of working practices (multitasking, adaptation of new media and technologies) and organizational shifts reflecting economic and societal changes in the Polish mediascape over the last few years. 
All in all, examination of grey literature (corporate documentation, in-house codes of ethics, strategies and so on) followed by in-depth interviews with media professionals at all levels and ethnographic observations in the newsrooms could provide new insights to daily practices, the level of media openness as well as potential social and mental barriers for evolution and change.

\section{References}

Bertrand C. (2000), Media Ethics \& Accountability Systems, New Brunswick, Transaction Publishers, London.

de Haan L. (2012), Between Professional Autonomy and Public Responsibility: Accountability and Responsiveness in Dutch Media and Journalism, Ph.D. dissertation, Amsterdam School of Communication, Amsterdam, http://dare.uva. $\mathrm{nl} /$ document/352983, 12.04.2013.

Eberwein T., Fengler S., Philipp S., Ille M. (2014), Counting media accountability - The concept and methodology of the MediaAcT survey, in: Journalists and Media Accountability: An International Study of News People in the Digital Age, eds. S. Fengler, T. Eberwein, G. Mazzoleni, C. Porlezza, S. Russ-Mohl, Peter Lang Publishing, New York.

EBU (2015), Governance Principles of Public Service Media, European Broadcasting Union, Geneva.

Evers H., Groenhart H. (2010), The role of technology in the accountability process. Facilitating and changing context, Paper presented during theoretical workshop of projekt MediaAcT, Tartu, June 12, 2010.

Fengler S., Eberwein T., Leppik-Bork T. (2011), Mapping Media Accountability in Europe and Beyond, in: Mapping Media Accountability in Europe and Beyond, eds. T. Eberwein, S. Fengler, E. Lauk, T. Leppik-Bork, Herbert von Halem, Koln.

Fengler S. (2012), From media self-regulation to 'crowd-criticism': Media accountability in the digital age, "Central European Journal of Communication", vol. 2 (9), pp. 172-189.

Głowacki M. (2015), Governance of Public Service Media in Poland: The Role of the Public, "Media and Communication", vol. 3, no. 4, pp. 26-34.

Groenhart H., Evers H. (2014), Media Accountability and Transparency - What Newsrooms (Could) Do, in: Journalists and Media Accountability: An International Study of News People in the Digital Age, eds. S. Fengler, T. Eberwein, G. Mazzoleni, C. Porlezza, S. Russ-Mohl, Peter Lang Publishing, New York.

Heikkilä H., Domingo D., Pies J., Głowacki M., Kuś M., Baisnée O. (2012), Media accountability goes online. A transnational study of emerging practices and 
innovations, MediaAcT Working Paper no. 14/2012, http://www.mediaact.eu/ fileadmin/user_upload/WP4_Outcomes/WP4_Report.pdf, 8.01.2016.

Heikkilä H., Głowacki M., Kuś M., Pies J. (2014), Innovations in Media Accountability and Transparency, in: Journalists and Media Accountability: An International Study of News People in the Digital Age, eds. S. Fengler, T. Eberwein, G. Mazzoleni, C. Porlezza, S. Russ-Mohl, Peter Lang Publishing, New York.

Jenkins H., Ford S., Green J. (2013), Spreadable Media: Creating Value and Meaning in a Networked Culture, New York University Press, New York.

Kuś M. (2011), Poland: waiting for citizens to demand online media accountability, MediaAcT Working Paper no. 8/2011 on Media Accountability and Transparency, http://www.mediaact.eu/fileadmin/user_upload/WP4/WP4_Poland.pdf, 16.01.2016.

Nygren G., Dobek-Ostrowska B. (eds.) (2015), Journalism in Change: Journalistic Culture in Poland, Russia and Sweden, Peter Lang Publishing, Frankfurt am Main-Bern-Bruxelles-New York-Oxford-Warszawa-Wien.

Shirky C. (2008), Here Comes Everybody, Penguin Books, London.

Stępińska A., Ossowski S. (2011), Dziennikarze w Polsce: wartości, priorytety i standardy zawodowe [Journalists in Poland: values, priorities and professional standards], "Studia Medioznawcze", vol. 1, pp. 17-30.

Szot L. (2013), Dziennikarze mediów lokalnych w Polsce-między profesjonalizmem a koniecznościq przetrwania [Journalists of local media in Poland - between professionalism and necessity of survival], Wydawnictwo Uniwersytetu Wrocławskiego, Wrocław.

Van Dijck J. (2013), The Culture of Connectivity. A critical History of Social Media, Oxford University Press, Oxford.

von Krogh T. (2012), Understanding Media Accountability. Media Accountability in Relation to Media Criticism and Media Governance in Sweden 1940-2010, Mid Sweden University, Sundsvall.

Wyss V., Keel G. (2009), Media Governance and Media Quality Management: Theoretical concepts and an empirical example from Switzerland, in: Press Freedom and Pluralism in Europe: Concepts and Conditions, eds. A. Czepek, M. Hellwig, E. Nowak, Intellect, Bristol, Chicago. 
